\title{
ANALYSIS OF BASIC COFFEE KNOWLEDGE LEVELS OF MILLENNIALS IN BANDUNG
}

\author{
Dissy Hilmina, Agus Sudono
}

Indonesia University of Education, Jl. Dr. Setiabudhi No. 229, Bandung 40154, Indonesia

*Corresponding Author's E-mail: dissyhilmina@student.upi.edu (Dissy Hilmina)

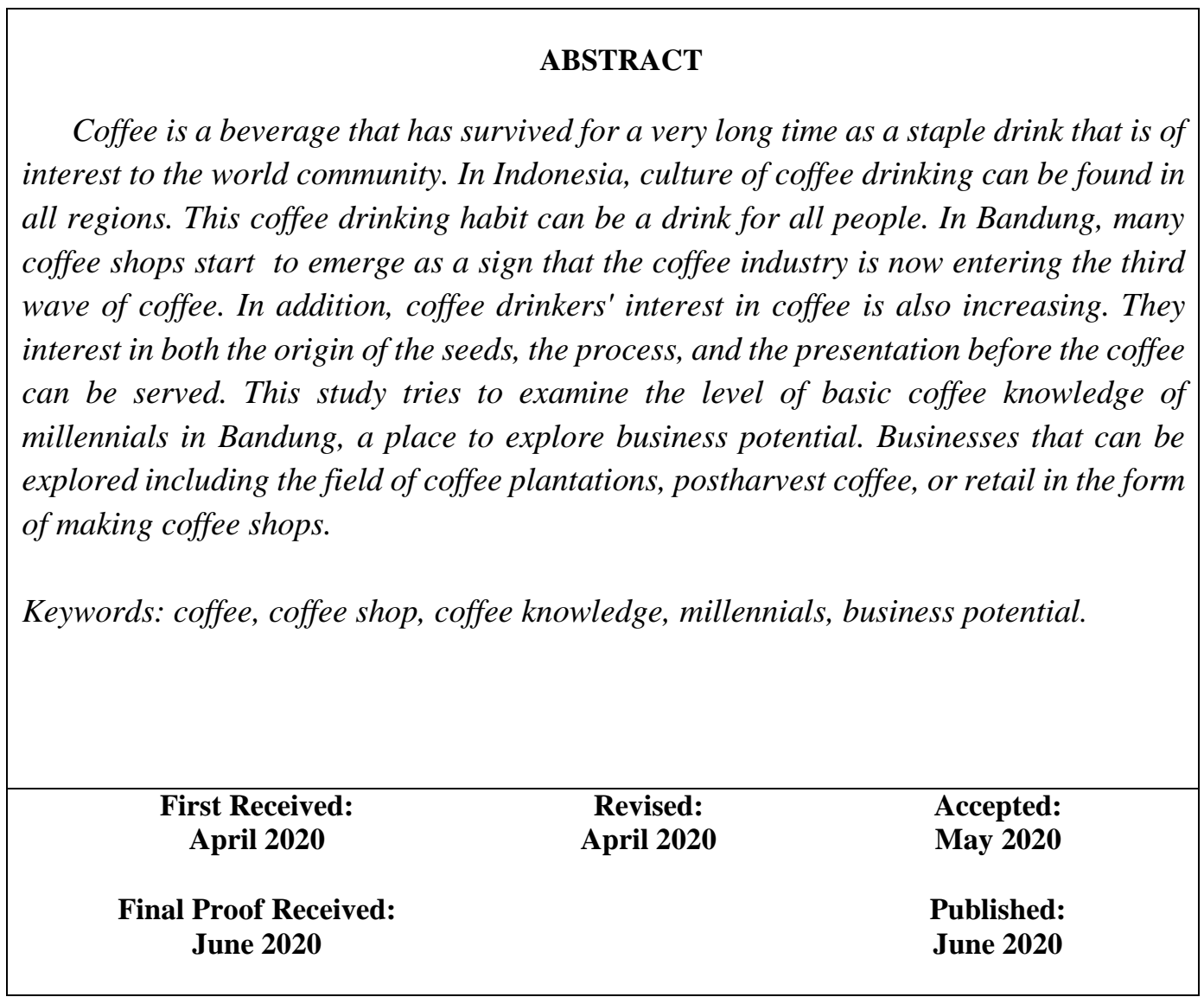




\section{Introduction}

Coffee was first available only in Ethiopia. Native seeds are planted by highland Ethiopians. Ethiopians brought coffee to the Arab countries. Coffee plants in Arabia began to be planted and sold until North Africa. After being planted en masse, the coffee beans originated North Africa spreaded widely from Asia to Europe. Coffee's fame as a drink spread through travelers, merchants, and invaders throughout the world. Coffee entered Indonesia in the 17th century when Indonesia was still under the Dutch colony, namely the VOC, who brought coffee plants into the country. (Hans Rooseboom, 2014).

Indonesia makes coffee as a mainstay with abundant agricultural commodity potential. As an agrarian country, agricultural commodities are certainly the backbone of the Indonesian economy. In addition, Indonesian agricultural commodities are not only traded in the domestic market, but also in the international market or known as exports. Export activities certainly increase the country's revenues. Based on data from the Directorate General of Estate Crops of Indonesia(2018), $67 \%$ of total coffee production in Indonesia is exported, while $33 \%$ is maintained to meet domestic coffee needs. FAOSTAT (2016) states that Indonesia as the fourth largest coffee producing country in the world in 2015, after Brazil, Vietnam, and Colombia.

According to Adhi Prakoso (2019), now coffee has entered the era of third wave coffee. The first wave was marked by the emergence of coffee industrialization and the emergence of instant coffee in this era. The second wave was marked by the presence of a coffee shop that introduced coffee drinks with high creativity that attracted young people. Coffee shop chains like Starbucks from the United States has opened hundreds of branches all over the world. The third wave is the current era marked by a movement that coffee should be appreciated like art. Coffee consumers in this era seem to

care more about the origin of coffee from its farmers to the presentation of coffee with sophisticated equipment. This development is supported by numerous offers of full-time or part-time work as baristas in coffee shops in major cities in Indonesia such as Bandung. To become a barista, one needs basic coffee knowledge to support the capabilities of millennials who want to focus on the coffee industry. Accordingly, this study aims to find out how good the basic coffee knowledge of young people is. Thus, the problems are formulated as follows.

a. How is the basic coffee knowledge level of millennials in Bandung?

b. How does knowledge about coffee affect the business potential of millennials' coffee shops in Bandung?

\section{Literature Review}

2.1. The Concept of Knowledge

According to Donsu (2017), knowledge is an important domain in the formation of open behavior. Knowledge is the result of human sensing or the result of knowing someone about an object through the senses they have.

\subsection{Definition Business}

The word business comes from the English bussines which means one of the business activities in supporting economic development. Business broadly means a general term that describes an activity and institution that produces goods and services in daily life (Amirullah, 2005: 2).In business there are ethics to follow.

Business ethics can be described as knowledge of the ideal way of setting up and managing business by observing morality and norms universally to prolong business activities (Muslich, 2004). According to Murti Sumarni (1995), business ethics related to the problem of assessing business activities and conduct that lead to truth and honesty. Thus, business ethics can be described as systems of business regulation and management that observe norms and morality that lead to truth and honesty. 


\subsection{Business Opportunities Knowledge}

Hendro (2011:141) stated that there are four steps to create an opportunity as a golden opportunity.

a. Find the source of opportunity

One's being is the most potential source of opportunity. Having an interest in something is the first step before doing research and trial to find opportunities in the right segment.

b. Find business sector

The power of opportunity is at the power of the right business sector so that it is important to choose the right one. The power of a proper business is the void of the market.

c. Take advantage of the power of products in order to have sales value

If the right opportunity does not have a high sales value, it will be useless because the products wil not meet the market need. This process is very important at this stage.

d. Evaluate and take advantage of opportunities to become products

The last step is to take advantage of opportunity by assessing and analyzing success factors and business opportunity failure factors, then develop into a product for potential business.

\subsection{Definition of coffee shop}

According to Poerwadarminta (1986), a coffee shop is a place to sell coffee and other drinks and cheap snacks. Coffee shop can be a place for people who want to relax or do other (light) activities, such as having discussion or conversation, reading online or printed books, completing some academic or non-academic tasks or having fun with the entertainment offered (Nurazizi, 2013). In short, coffee shop is the place that sells coffee, drinks, and light foods at relatively cheap prices, where people gather to relax or do light activities.

\subsection{Millennials}

Millenials or Generation Y, also known as Generation Me or Echo Boomers, born in 1980 to 1999 . Many similarities with the Baby Boomers generation, millennial generations look physically different with piercing, tattoo, also using electronic tools, such as iPods, smart phones, and laptops (Hira, 2007). This generation can adapt to change and more prosperous, smarter technology, educated, more ethnically diverse than the previous generation (Spiro, 2006). According to Artley and Macon (2009), millennials communicate through social media, websites, and emails hoping to get instant feedback, but sometimes they have poor communication skills and problem solving.

Although they are poor in problem solving and communication, this generation is always sought after, needed, because people has higher expectations on them than the previous generation. They also have positive energy and skills that are deemed sufficient, but are often criticized for having a short attention span and unwillingness to do simple tasks (Spiro, 2006).

\section{Research Methods}

The object of this study is the level of basic coffee knowledge, and Bandung millennials as the subject. This type of research is a descriptive study with qualitative and quantitative mix methods. The technique that researchers use in sampling is the non-probability sampling technique, which uses the Wibisono formula in Riduwan and Akdon (2013).

Tabel 1. Sample Formulation of Wibisono

$$
\begin{gathered}
\mathrm{n}=\left\{\frac{(\mathrm{Za} / 2) \cdot \sigma}{e}\right\}^{2} \\
\mathrm{n}=\left\{\frac{(1,96 / 2) \cdot 0,25}{5 \%}\right\}^{2} \\
\mathrm{n}=96,04 \text { rounded off } 100
\end{gathered}
$$

$\mathrm{n}=$ amount of samples

$\mathrm{Za} / 2=$ the value of the normal distribution table for the level of confidence $95 \%=1,96$.

$\sigma=$ standar deviation $25 \%$

$\mathrm{e}=$ error $($ error limit $=5 \%)$ 
From the calculation of Wibisono in Riduwan and Akdon (2013), the minimum sample size of 96.04 respondents was rounded to one hundred respondents. In this study the sample used was 200 respondents who are millennials in Bandung and have an interest in coffee.

\section{Results and Discussion}

\subsection{Respondent Data}

The results of the analysis of the basic coffee knowledge and millennials' business potential in Bandung show that 180 respondents in this study were generally aged between 21-30 years or equivalent to $90 \%$. Most of the respondents of this study were women, namely 127 people (63\%). Most of the respondents in this study were 113 students (56\%) and lastly the monthly income of the respondents in this study were mostly <Rp. 1,000,000.

4.2. Distribution of Respondents 'Answers on Coffee Basic Knowledge Variables

On coffee basic knowledge variables aim to see the extent to which respondents know coffee. The details are as follows.

Table 2. The respondents' answers distribution in the basic coffee knowledge variable

\begin{tabular}{ccccc}
\hline No. & Variabel & True & False & $(\%)$ \\
\hline 1. & X1 & 198 & 2 & $99 \%$ \\
2. & X2 & 190 & 10 & $95 \%$ \\
3. & X3 & 171 & 29 & $86 \%$ \\
4. & X4 & 177 & 23 & $89 \%$ \\
5. & X5 & 195 & 5 & $98 \%$ \\
6. & X6 & 179 & 21 & $90 \%$ \\
7. & X7 & 181 & 19 & $91 \%$ \\
8. & X8 & 192 & 8 & $96 \%$ \\
9. & X9 & 171 & 29 & $86 \%$ \\
10. & X10 & 182 & 18 & $91 \%$ \\
11. & X11 & 170 & 30 & $85 \%$
\end{tabular}

\begin{tabular}{|c|c|c|c|c|}
\hline No. & Variabel & True & False & $(\%)$ \\
\hline 12. & X12 & 181 & 19 & $91 \%$ \\
\hline 13. & X13 & 192 & 8 & $96 \%$ \\
\hline 14. & X14 & 192 & 8 & $96 \%$ \\
\hline 15. & X15 & 173 & 27 & $87 \%$ \\
\hline 16. & X16 & 179 & 21 & $90 \%$ \\
\hline 17. & X17 & 51 & 149 & $26 \%$ \\
\hline 18. & X18 & 178 & 22 & $89 \%$ \\
\hline 19. & X19 & 193 & 7 & $97 \%$ \\
\hline 20. & X20 & 173 & 27 & $87 \%$ \\
\hline 21. & X21 & 168 & 32 & $84 \%$ \\
\hline 22. & X22 & 184 & 16 & $92 \%$ \\
\hline 23. & $\mathrm{X} 23$ & 185 & 15 & $93 \%$ \\
\hline 24. & X24 & 182 & 18 & $91 \%$ \\
\hline 25. & X25 & 181 & 19 & $91 \%$ \\
\hline 26. & X26 & 194 & 6 & $97 \%$ \\
\hline 27. & $\mathrm{X} 27$ & 182 & 18 & $91 \%$ \\
\hline 28. & X28 & 191 & 9 & $96 \%$ \\
\hline 29. & X29 & 168 & 32 & $84 \%$ \\
\hline \multirow[t]{3}{*}{30.} & X30 & 58 & 142 & $29 \%$ \\
\hline & $\begin{array}{c}\text { Amount } \\
\text { data }\end{array}$ & 5211 & 789 & 6000 \\
\hline & $\begin{array}{r}\text { Presentase } \\
\text { Average }\end{array}$ & $87 \%$ & $13 \%$ & $100 \%$ \\
\hline
\end{tabular}

4.3. The respondents answer distribution in business potential variables

\begin{tabular}{ccccc}
\hline No. & Variabel & True & False & $(\%)$ \\
\hline 1. & Y1 & 71 & 129 & $36 \%$ \\
2. & Y2 & 156 & 44 & $78 \%$ \\
3. & Y3 & 144 & 56 & $72 \%$ \\
4. & Y4 & 119 & 81 & $60 \%$ \\
5. & Y5 & 141 & 59 & $71 \%$ \\
& Amount data & 631 & 369 & 1000 \\
X \% & $63 \%$ & $37 \%$ & $100 \%$ & $\mathrm{X} \%$ \\
& & & & \\
\hline
\end{tabular}


Data in table 2 shows that the majority of respondents already know a lot about coffee with the correct answer of 5,211 statements or equivalent to $87 \%$ of the 6,000 statement items for 200 respondents. Meanwhile, the wrong answers were $13 \%$ or 789 statements. It can be concluded that millennials in Bandung have basic knowledge of good quality coffee. However, they are not necessarily want and able to have a business in the coffee sector.

\subsection{Distribution of Respondents 'Answers on Business Potential Variables \\ The results of the distribution of} respondents' answers on business potential variables aim to see the business opportunities that exist in respondents. The details are as follows From the data processed in table 3 shows that the majority of respondents (129) did not know about coffee so well with a percentage of $36 \%$, and respondents who were interested in knowing coffee making were 156 respondents (78\%). There were 144 respondents who were interested in learning to make coffee (72\%) followed by 119 respondents who have interest in working as coffee makers $(60 \%)$. Finally, there were 141 respondents who were interested in making coffee-related businesses (71\%). It can be concluded that respondents who are Bandung millennials generally have good knowledge to start a business in the field of coffee.

\subsection{Discussion}

From the results of the distribution of respondents' answers on basic knowledge variable it can be concluded that the majority of respondents namely Bandung millennials already know a lot about coffee so they can start a business in the field of coffee that includes coffee plantations, postharvest coffee, or retail by making coffee shops.

\section{Conclusions}

Based on the data, data testing, data analysis, and research discussion, the following research conclusions can be drawn.
1. Bandung is a strategic place to start a business, especially in the coffee sector, due to the rise of new coffee shop business in Bandung that spread along the road. The development of the coffee business in Bandung certainly makes coffee entrepreneurs, most of whom are millennials, must have basic knowledge about coffee. After distributing the questionnaire, it was found that the majority of respondents in this study knew the basic knowledge of coffee with a total of $87 \%$ correct answers from all available statements so that Bandung millennials could be said to be good in the basic coffee knowledge.

2. Basic knowledge about coffee can also affect business potential because if knowledge about coffee is discovered, the opportunity to run a coffee-related business is broader. Not only in the field of coffee serving, millennials can also develop coffee plantations, coffee processing from beans to powder in packaging.

\section{References}

Akdon, Riduwan. 2013. Rumus dan Data dalam Analisis Statistika. Bandung : CV Alfabeta.

Amirullah, Hardjanto. 2005. Pengantar Bisnis, Edisi 1. Graha Ilmu, Yogyakarta

Direktorat Jendral Perkebunan. 2018. Statistik Perkebunan Indonesia 2018.

http://ditjenbun.pertanian.go.id.

Diakses 5 Juli 2020.

Donsu, J. D. T. 2017. Psikologi Keperawatan. Yogyakarta: Pustaka Baru Press

FAOSTAT. 2016. Food and Agriculture Organization. www.fao.org/home. Diakses 16 Desember 2019.

Hendro. 2011. Dasar-Dasar Kewirausahaan. Jakarta : Erlangga.

Muchlis. 2004. Etika Bisnis Islam. Jakarta : Ekonisia.

Nurazizi, RD. 2013. Kedai Kopi dan Gaya Hidup Konsumen. Malang : 
Universitas Brawijaya.

Poerwadarminta, W.J.S. 1986. Kamus

Besar Umum Indonesia. Jakarta :

Balai Pustaka.

Prakosa, Adhi. 2019. Generasi Third Wave

Coffee: Perspektif Milenial terhadap

Kopi Gelombang Ketiga. Yogyakarta.

Rooseboom, Hans. 2014. The History of

Coffee in Indonesia.

https://indonesiaexpat.biz/news/spill

ing-the-beans-on-jakartas-best-bouti

que-cafes/. Diakses 19 Desember 2019. 